\title{
Developments in the International Society of Biometeorology over the decade, 2007-2016
}

Marie R Keatley, School of Ecosystem and Forest Sciences, University of Melbourne, Creswick, Victoria, 3363 Australia

\begin{abstract}
Over the decade 2007-2016, the International Society of Biometeorology (ISB) has pursued its purpose of advancing the science of biometeorology through its Congresses and sponsoring conferences, meetings and workshops. In conjunction with Springer, ISB has introduced a new book series: Biometeorology, and published three volumes. ISB's journal, the International Journal of Biometeorology, has increased the number of issues to 12 per year and added the Fields of "Aerobiology", "Climate Change and Ecology" and "Climate Change and Public Health". Within ISB, there are currently six Commissions, reflecting the interests of the members and the needs of society. The newest, Biophysics of Adaptation and Response Commission, formed in 2015. Another group which formed over the decade was the Students and New Professionals Group. The Universal Thermal Climate Index Commission was formally dissolved in 2014 having met its aim of developing an easily understood human thermal index. At the Executive Board level, geographical representation has increased, with Councillors now being elected to represent six regions: Africa, Asia, Europe, Latin America and the Caribbean, Oceania, and Northern America. The ISB has worked to better coordinate and communicate biometeorological research, collaborating strategically with international partners to achieve this objective.
\end{abstract}

\section{Keywords}

International Society of Biometeorology, Commissions, International Journal of Biometeorology, history

\section{Introduction}

The early history of the International Society of Biometeorology (ISB) has been well documented (Weihe 1997; Tromp 1976; Sargent and Tromp 1966), but particular information is worth repeating. The first meeting of the Society was held in Paris at the UNESCO headquarters in August 1956; therefore 2016 marked the $60^{\text {th }}$ Anniversary of the official founding of the ISB by Solco W Tromp and Frederick Sargent (Sargent and Tromp 1966). For its first five years, the ISB was known as the International Society of Bioclimatology and Biometeorology, becoming ISB in 1961 (Tromp 1976).

The purpose of the ISB as laid out in the Statutes is to provide one international organization for the promotion of interdisciplinary collaboration of scientists concerned with the direct or indirect interaction between the atmosphere and all living organisms, and the development of the field of meteorology in relation to humans, other animals, and plants. 


\section{ISB Congresses and Sponsored Meetings}

To realise its purpose of developing biometeorology ISB supports, often in conjunction with the Tromp Fund, activities such as conferences, meetings and workshops. ISB's triennial Congresses are a focus, they provide the forum for the latest biometeorology research to be presented, current collaborations to be reinforced and for new interdisciplinary collaborations to be formed. Additionally, these congresses promote ISB and biometeorology to the wider scientific community. Over the last decade three congresses have been held, with the host countries reflecting the commitment of the ISB members organising the Congress in each city and the ISB's desire to hold consecutive Congresses in different regions.

In 2008 , the $18^{\text {th }}$ Congress was held in Tokyo, Japan. The theme for the congress was "Harmony within Nature"; delegates from 39 countries attended. The $19^{\text {th }}$ Congress was held in Auckland, New Zealand in 2011 and attracted delegates from 39 countries with the theme "Climate and Society". It was also the second time the Congress had been held in the southern hemisphere. "Adaption to Climate Risks" was the theme for $20^{\text {th }}$ Congress in 2014. It was held in Cleveland, USA with delegates from 42 countries.

The broader promotion of biometeorology and ISB over the last decade is illustrated by the examples below. These sometimes overlap with the activities of Commissions and/or Councillors.

In 2010, ISB co-sponsored the 'BIOMET 7 Conference', held in Freiburg, Germany. The other sponsors of the conference were the Albert-Ludwigs-University of Freiburg, the German Weather Service, the Central Institution for Meteorology and Geodynamics, Austria, the Expert Committee on Biometeorology of the German Meteorological Society, the Humboldt-University of Berlin, Germany, and the Society for the Promotion of Medicine-Meteorological Research in Germany. The conference had sessions on Agricultural meteorology, Forest Meteorology, Phenology, Climate and tourism, Biosphere and Regional climate change, and Human biometeorology. There were over 100 participants (Matzarakis et al. 2010), with ISB members amongst them.

The first international meeting on biometeorological and bioclimatic forecasts for Latin America and the Caribbean region was held in Havana, Cuba in 2015, organized by Luis B. Lecha Estela (Councillor, Latin America and the Caribbean) and Andrés H. Planas Lavié. The meeting was co-sponsored by the Cuban Meteorological Society (Lecha 2016).

The meeting brought together 30 experts ( 15 from Cuba and 15 internationals) from the different areas of biometeorology (humans, other animals and plants). These included various ISB members representing the Animal Biometeorology and Climate and Human Health Commissions. The meeting's sessions were:

- Biometeorological forecast services for human health,

- Experiences from the medical side during the application of biometeorological forecasts,

- Development of climate services for human health,

- Impacts of climate services on human health,

- Agrometeorology and phenology services for agriculture,

- Biometeorological services for animal health. 
In May 2016, ISB, through the Climate and Health Commission, supported the organization of the international, educational and capacity building workshop Global Change impact on diseases and alien species expansion. The workshop was developed by the African Institute for Mathematical Sciences and held in Cape Town, South Africa (Fernández de Arróyabe 2016). It was aimed at young researchers and postgraduates, attracting participants from 15 different African countries as well as China, Cuba, and the Philippines. Local and international experts, ISB President-Elect Pablo Fernández de Arróyabe among them, gave mini courses and lectures (see https://www.youtube.com/playlist?list=PLTBqohhFNBE9ZLTRj1RnvSarzu4tA3BIQ). interdisciplinary nature of the workshop with participants with backgrounds in mathematical sciences, medicine, climate, forestry and economics is reinforced by the other supporting partners: International Mathematical Union; International Union of Biological Sciences; International Union of Immunological Societies; International Union of Microbiological Societies; International Social Science Council, International Council of Industrial and Applied Mathematics; ICSU Regional Office for Africa; ecoHEALTH from Future Earth; South African Mathematical Society; DST-NRF Centre of Excellence for Invasion Biology; and Mathematics of Planet Earth.

In 2016, ISB sponsored the first session on Biometeorology organised at an International Geographical Congress. The Congress was held in August in China. The session on Global Change and Biometeorology was included under the key topic of Climate Change and Global Understanding and was organised by ISB members Pablo Fernández de Arróyabe Hernáez and Junhu Dai (Councillor, Asia). The session had presentations across each of the broad fields of biometeorology: humans, animals and plants.

\section{International Relations}

The ISB has become recognised as "a focus for bioclimatological studies" (Maarouf and Munn 2005). This is reflected in the formal relationships that ISB has fostered, since the 1960s, with international organizations such as the Food and Agriculture Organization, the World Health Organization, and the World Meteorological Organization (Beggs 2000; Love 2011; Commission for Agricultural Meteorology 2015; Weihe 1967).

The strength of these relationships varies over time according to the needs of each organization. Examples are given by ISB having consultative status with World Meteorological Organization since 1963 and in 2000 a Memorandum of Understanding being entered into by the two organizations (Beggs 2000). In 2011, ISB was recognised by the World Meteorological Organization as a partner in the development of a heat waves and health warning system (Love 2011). The Guidelines were published jointly in 2015 by the World Meteorological Organization and World Health Organization with significant contributions from members of ISB (McGregor et al. 2015).

Additionally, since the 1970s ISB has formalised relationships with likeminded societies (Tromp 1970). This enables closer co-operation, the exchange of ideas and knowledge and the ability to share resources. Currently, ISB is affiliated with the following societies: American Meteorological Society, Center for Renewable Energy Sources and Saving, German Meteorological Society, International Society of Medical Hydrology and Climatology, International Society of Zoological Sciences, International Union of Biological Sciences, United Kingdom Met Office and Society for the Promotion of Medicine-Meteorological Research. ISB is also a member of the International Forum of 
Meteorological Societies which provides ISB with an efficient method of maintaining links with the other 60 plus meteorological societies of the world.

\section{Executive Board}

Over its history, ISB has had members from 23 countries and varying disciplines serve on the Executive Board (Appendix 1). However, similar to publications within the International Journal of Biometeorology, membership has been dominated by Europe and North America (Sheridan and Allen 2017), reflecting in part the nationalities of the founders and early membership of the Society. Consequently, in 2011 the Executive Board discussed that membership of the Board should have broader geographical representation. The Board believed that this would occur if Councillors included representation from the following six regions: Africa, Asia, Europe, Latin America and the Caribbean, Oceania, and Northern America. The regions were based on the United Nations Statistics Division's Geographic regions (United Nations Statistics Division 1999). The members of ISB approved this prior to the 2014 election, therefore since these elections the number of Councillors has increased from three to six (Appendix 1). Councillors act as a point of contact for members in a geographical area and if needed as a conduit to the Board (Tromp 1976). They also promote ISB and its purposes.

\section{Commissions}

Commissions and Study Groups (previously called Permanent Standing Committees when ISB was first founded (Sargent and Tromp 1966)) have varied in number and discipline over the years, reflecting both the diverse and interdisciplinary nature of ISB and the needs of society. For example, in 1975 there were 11 study groups (e.g. Effects of weather and climate on human health and disease, Biological effects of natural electric, magnetic and electromagnetic fields) (Anon 1975), while in 2008 there were five (e.g. Animal Biometeorology, Universal Thermal Climate Index) (Kalkstein 2008).

As ISB enters its seventh decade there are currently six groups: Animal Biometeorology Commission, Biophysics of Adaptation and Response Commission, Climate and Human Health Commission, Commission on Climate, Tourism and Recreation, Phenology Commission, and the Students and New Professionals Group (see de Freitas in press; Vanos in press for greater details on individual Commissions). Each group has its own aims, in addition to supporting the broader aims of the Society. The Biophysics of Adaptation and Response Commission is the newest commission, forming in 2015, with the following objectives:

- Create biophysical models of thermoregulation, immune response, and acclimatization for animals and humans.

- Explain statistical associations established across the field of biometeorology.

- Being a research ambassador with projects Exposome and Physiome, aimed at understanding the response of humans under different environmental exposures.

- Develop and promote guidelines for preventing and/or mitigating the impact of adverse weather conditions.

The Students and New Professionals Group (SNP) commenced in 2008 under the chair of Kate Bassil, with its first official meeting at the $18^{\text {th }}$ International Congress in Tokyo, Japan (Kalkstein 2008). 
Membership is open to those people who are either within five years from leaving education (e.g. PhD study) or under 35 years of age (Gosling 2014). SNP has been active since is foundation, with support from ISB and the Tromp Foundation. To date, its members have:

- published a glossary of biometeorology (Gosling et al. 2014);

- held two international workshops

- "Extending the application of climate and health research tools into distinct climate regimes in India, Russia and New Zealand" Sweden in June 2014

- "Enhancing the Teaching and Learning of Biometeorology in Higher Education" USA in July 2016

- contributed to a special issue of ISB's journal, based on papers presented at the $19^{\text {th }}$ International Congress held in Auckland, New Zealand in 2011. (Gosling 2014). SNP are planning a second special issue based on papers for the upcoming $21^{\text {st }}$ International Congress in Durham, United Kingdom in September 2017 (Sheridan and Allen 2017)

- organised an early career development workshop held at the $20^{\text {th }}$ International Congress, Cleveland, USA in 2014. Two workshops are planned to be held at the $21^{\text {st }}$ International Congress: early career development and biometeorology education outreach (Vanos in press)

- started a Biometeorology Quarterly Newsletter in 2015 specifically for SNP

- launched its own website in 2016: http://biomet-education.net

- launched a Twitter account: @biometeorology (see Vanos in press for greater details on SNP)

As expected (Höppe 1995), the Commissions with financial support from ISB also hold their own disciplined focussed conferences. For example, since its initiation in 1996 at the $14^{\text {th }}$ International Congress in Slovenia the Commission on Climate, Tourism and Recreation has held four conferences (de Freitas and Scott 2015). By 2012, the first three conferences (2001, 2004 and 2007 (de Freitas et al. 2007)) were recognised as having produced the largest body of research in the field (Scott et al. 2012). In 2009, the Commission also produced a white paper on weather and climate information for tourism for the World Meteorological Organization and the United Nations World Tourism Organization (Scott and Lemieux 2009).

Over the last decade, the Phenology Commission has been involved with three international conferences (2010, 2012 and 2015), two of which have resulted in special issues in the International Journal of Biometeorology (Table 1). At the 2015 Conference, the Commission also formed a working group to collaborate with the World Meteorological Organization's Commission for Agricultural Meteorology on international standards for phenology.

The Universal Thermal Climate Index Commission commenced in 2001 (Jendritzky and Höppe in press) with the aim of developing an easily understood human thermal index which could be applied across scales, seasons and climates, based on the latest research in thermo-physiological modelling (McGregor 2012). The program involved over 45 scientists from 23 countries across three working groups (Jendritzky et al. 2012) from multiple disciples (e.g. human thermophysiology, physiological modelling, meteorology and climatology (Błażejczyk et al. 2013)). In 2005, the program formed the basis of the Cooperation in Society and Technology (COST) Action 730 which also worked under World Meteorological Organization's Commission on Climatology (Jendritzky et al. 2012). By 2009, the index had been developed and the program was brought to a close (Jendritzky and Kalkstein 2015) with a final presentation at the World Meteorological Organization's headquarters in 
April 2009. The Commission was formally dissolved, as required by the ISB's statues, by the Executive Board at its 2014 meeting at the $20^{\text {th }}$ Congress in Cleveland, Ohio.

\section{International Journal of Biometeorology}

As a scholarly society, ISB has produced a journal since 1957 (Tromp 1976). ISB is fortunate that it has had a strong relationship with Springer, a leading academic publisher, since 1988 (Lieth 1988). The strength of the relationship is reflected, in part, by having the same Springer Editor until 2010, Dieter Czeschlik. On his retirement in 2010, Margaret Deignan became the Springer Editor. At the same time the publishing responsibility for the journal moved to the Environmental Sciences Unit at the Dordrecht office in The Netherlands (pers. com. M. Deignan).

Since 1957, the journal has had eight Editors-in-Chief (who are also members of the Executive Board) (Table 2). The journal's latest Editor-in-Chief, Scott Sheridan commenced in 2008.

Under Sheridan's editorship the journal has increased the number of issues published per year: firstly from six to ten in 2014 and then to twelve in 2015. This reflects in part the increased rate of submissions enabled by the introduction of the editorial management system in 2006 (Sheridan and Allen 2017). Special issues have become a feature over the last decade, with six having been published (Table 1) (Sheridan and Allen 2017). Additionally, after an absence of a decade, Short Communications as a submission option was re-introduced in 2009 (Sheridan 2009).

In 2011, the journal added the fields of "Climate Change and Ecology" and "Climate Change and Public Health" (Beggs 2014) and in 2014 Aerobiology (Beggs et al. in press; Sheridan and Allen 2017). Currently, the journal has seven other fields: agricultural meteorology, animals, epidemiology, forests, humans, phenology, thermal environment, and urban biometeorology.

\section{Biometeorology Series}

In 2009, ISB in conjunction with Springer introduced a new book series: Biometeorology. As stated on the website (http://www.springer.com/series/8101) the purpose of the series is to:

- communicate the interdisciplinary philosophy and science of biometeorology to as wide an audience as possible,

- introduce scientists and policy makers to the societal relevance of and recent developments in its subfields,

- demonstrate how a biometeorological approach can provide entry points to the understanding and possible solution of cross-cutting environmental issues such as climate change, desertification, deforestation, biodiversity loss, land degradation, emerging diseases and the availability of clean water and air

The series Chief editor and the editorial board are all members of ISB (Beggs 2009). So far there have been three volumes published:

- Biometeorology for Adaptation to Climate Variability and Change. This volume was published to mark the $50^{\text {th }}$ anniversary of ISB (Ebi et al. 2009),

- Principles of Animal Biometeorology (Gomes da Silva and Sandro Campos Maia 2013),

- Boreal and Temperate Trees in a Changing Climate (Hänninen 2016). 


\section{Conclusions}

ISB has promoted the science of biometeorology over the last decade through conferences, meetings and workshops, the creation of a book series focussed on biometeorology and the work of individual commissions. Submissions to the journal have increased sufficiently to warrant 12 issues a year. The Executive Board now has inherent geographical representation with individual Councillors representing six major regions of the world. For ISB to continue to develop and to contribute to the advancement of biometeorology the membership of ISB needs to remain engaged and active.

\section{Acknowledgements}

Many thanks to Margaret Deignan, Springer and ISB colleagues who provided information for this article: Lynda Chambers, Robert Davis, Xiaoqiu Chen, Pablo Fernández de Arróyabe Hernáez, Elena Grigorieva, LeRoy Hahn, Gerd Jendritzky, Adam Kalkstein, Larry Kalkstein, Luis B. Lecha Estela, Mark Schwartz, Scott Sheridan and Jennifer Vanos. Additionally, my thanks to Tim Fletcher and the two referees who provided useful suggestions for improving the paper.

\section{References}

Anon (1975) Organization of the International Society of Biometeorology on 1st of January 1975. Int J Biometeorol 19 (Supplement 1):3-6

Beggs PJ (2000) Memorandum of Understanding (MOU) between the World Meteorological Organization (WMO) and the International Society of Biometeorology (ISB). Int J Biometeorol $44(4): 212$

Beggs PJ (2009) ISB news July 2009. Int J Biometeorol 53 (4):377

Beggs PJ (2014) Climate change and biometeorology, the International Society of Biometeorology and its journal: a perspective on the past and a framework for the future. Int J Biometeorol $58(1): 1-6$

Beggs PJ, Šikoparija B, Smith M (in press) Aerobiology in the International Journal of Biometeorology, 1957 - 2017. Int J Biometeorol doi: 10.1007/s00484-017-1374-5

Błażejczyk K, Jendritzky G, Bröde P, Fiala D, Havenith G, Epstein. Y, Psikuta A, Kampmann B (2013) An introduction to the Universal Thermal Climate Index (UTCI). Geogr Pol 86 (1):5-10

Commission for Agricultural Meteorology (2015) CAgM Report to ICG-WIGOS-4. https://www.wmo.int/pages/prog/www/WIGOS.../ICG-WIGOS-4/7.4 CAgM.pptx Date Accessed 01/05/2015

de Freitas C (in press) Tourism climatology past and present: a review of the role of the ISB Commission on Climate, Tourism and Recreation. Int J Biometeorol

de Freitas CR, Matzarakis A, Scott D (2007) Climate, Tourism and Recreation: a decade of the ISB's Commission on Climate, Climate, Tourism and Recreation. Paper presented at the Developments in Tourism Climatology, Alexandroupolis, Greece,

de Freitas CR, Scott D Foreward. In: Demiroğlu OC, de Freitas CR, Scott D, Kurnaz ML, Ünalan D (eds) The 4th International Conference on Climate, Tourism and Recreation - CCTR2015, Istanbul, Turkey, 2015. Istanbul Policy Center, Istanbul, pp 11-12

Donnelly A, O'Neill BF, Caffarra A, Schwartz MD (2011) Special Issue, Phenology 2010 Conference, Dublin, Ireland. Int J Biometeorol 55 (6):751-752

Ebi K, Burton I, McGregor GR (eds) (2009) Biometeorology for adaptation to climate variability and change. Biometeorology, vol 1. Springer, Dordrecht

Fernández de Arróyabe P (2016) Global Change impact on diseases and alien species expansion. Biometeorology Bulletin 18 (2):3-7

Gomes da Silva R, Sandro Campos Maia A (2013) Principles of animal biometeorology, vol 2. Biometeorology. Springer, Dordrecht 
Gosling SN (2014) New insights into biometeorology. Int J Biometeorol 58 (2):101-102

Gosling SN, Bryce EK, Dixon PG, Gabriel KMA, Gosling EY, Hanes JM, Hondula DM, Liang L, Bustos Mac Lean PAB, Muthers S, Nascimento ST, Petralli M, Vanos JK, Wanka ER (2014) A glossary for biometeorology. Int J Biometeorol 58 (2):277-308

Hänninen $\mathrm{H}$ (2016) Boreal and temperate trees in a changing climate, vol 3. Biometeorology. Springer, Dordrecht

Höppe P (1995) Study groups of the International Society of Biometeorology. Int J Biometeorol 38:162-165

Jendritzky G, de Dear RJ, Havenith G (2012) UTCI-Why another thermal index? Int J Biometeorol 56 (3):421-428

Jendritzky G, Höppe P (in press) The UTCl and the ISB. Int J Biometeorol

Jendritzky G, Kalkstein L (2015) Assessment of heat stress. In: Mcgregor GR, Bessemoulin P, Ebi K, Menne B (eds) Heatwaves and health: guidance on warning-system development. World Meteorological Organization and World Health Organization, Geneva, Switzerland, pp 14-24

Kalkstein LS (2008) ISB news November 2008. Int J Biometeorol 52:881

Lecha L (2016) Expert Meeting on Biometeorological and Bioclimatic Forecasts, Havana, Cuba. Biometeorology Bulletin 18 (1):4-6

Lieth $\mathrm{H}$ (1988) Editorial: starting a new term for the International Journal of Biometeorology. Int J Biometeorol 32:1-10

Love G (2011) WMO initiatives and partnerships. Inter-Agency consultation meeting on user interface platform (UIP): health and disaster risk reduction for the GFCS:https://www.wmo.int/gfcs/node/320

Maarouf AR, Munn RE (2005) Bioclimatology. In: Oliver JE (ed) Encyclopedia of world climatology. Springer, Dordrecht, pp 158-164

Mader T, Nienaber J, Brown-Brandl T (2010) Foreword to special issue LeRoy Hahn. Int J Biometeorol 54 (6):599

Matzarakis A, Mayer H, Chmielewski F-M (eds) (2010) Proceedings of the 7th conference on biometeorology. Meteorological Institute, Albert-Ludwigs-University of Freiburg, Germany Freiberg, Germany

McGregor GR (2012) Special issue: Universal Thermal Comfort Index (UTCI). Int J Biometeorol 56 (3):419-419

McGregor GR, Bessemoulin P, Ebi K, Menne B (2015) Heatwaves and health: guidance on warningsystem development. vol WMO No 1142. World Meterological Organization and World Health Organization, Geneva, Switzerland

Meze-Hausken E (2007) Grasping climate perceptions as an issue of measuring climate impacts on society. Int J Biometeorol 52 (1):1-2

Sargent F, Tromp SW (1966) The first decade of the International Society of Biometeorology (19561966). Int J Biometeorol 10 (3):207-214

Schwartz MD, Donnelly A (2014) Special Issue, Phenology 2012 conference, Milwaukee, WI, USA. Int J Biometeorol 58 (4):417-417

Scott D, Hall CM, Gössling S (eds) (2012) Tourism and Climate Change: Impacts, Adaptation and Mitigation. Routledge, London and New York

Scott D, Lemieux C (2009) Weather and climate information for tourism. White Paper commissioned for the World Climate Conference 3. World Meteorological Organisation and the United Nations World Tourism Organisation, Geneva and Madrid

Sheridan SC (2009) ISB news January 2009. Int J Biometeorol 53:125

Sheridan SC, Allen MJ (2017) Sixty years of the International Journal of Biometeorology. Int J Biometeorol. doi:10.1007/s00484-017-1366-5

Tromp SW (1970) Reports and news. Affiliations of national societies of biometeorology to the International Society of Biometeorology. Int J Biometeorol 14 (3):321-322 
Tromp SW (1976) The twentieth anniversary of the International Society of Biometeorology 1 January 1956 -- 1 January 1976. Int J Biometeorol 20 (2):71-91

United Nations Statistics Division (1999) Standard country or area codes for statistical use (M49). Geographic regions. https://unstats.un.org/unsd/methodology/m49/. Accessed 24/02/2017

Vanos JK (in press) An update from the Chair of the Students and New Professionals Group of the International Society of Biometeorology. Int J Biometeorol

Weihe WH (1967) Cooperation between WHO and ISB. Int J Biometeorol 11 (3):239-240

Weihe WH (1997) Review on the history of the International Society of Biometeorology. Int J

Biometeorol 40 (1):9-15 
Table 1: Special issues in the International Journal of Biometeorology 2007-present

\begin{tabular}{|c|c|c|c|c|}
\hline Special Issue Title & Month Year & \begin{tabular}{|l} 
Volume \\
(Issue)
\end{tabular} & $\begin{array}{l}\text { Page } \\
\text { Numbers }\end{array}$ & Editors \\
\hline Climate and Perception & October 2007 & $52(1)$ & $1-85$ & $\begin{array}{l}\text { (Meze-Hausken } \\
\text { 2007) }\end{array}$ \\
\hline Special issue honoring LeRoy Hahn & $\begin{array}{l}\text { November } \\
2010\end{array}$ & $54(6)$ & $599-663$ & $\begin{array}{l}\text { (Mader et al. } \\
\text { 2010) }\end{array}$ \\
\hline $\begin{array}{l}\text { Phenology 2010: Climate Change } \\
\text { Impacts \& Adaptations }\end{array}$ & $\begin{array}{l}\text { November } \\
2011\end{array}$ & $55(6)$ & $751-933$ & $\begin{array}{l}\text { (Donnelly et al. } \\
\text { 2011) }\end{array}$ \\
\hline $\begin{array}{l}\text { Universal Thermal Climate Index } \\
\text { (UTCI) }\end{array}$ & May 2012 & $56(3)$ & $419-555$ & $\begin{array}{l}\text { (McGregor } \\
2012 \text { ) }\end{array}$ \\
\hline $\begin{array}{l}\text { Special Issue: Articles from the } \\
\text { Students and New Professionals } \\
\text { group of the ISB }\end{array}$ & March 2014 & $58(2)$ & $101-308$ & (Gosling 2014) \\
\hline $\begin{array}{l}\text { Phenology 2012: Future climate \& } \\
\text { the living planet }\end{array}$ & May 2014 & $58(4)$ & $417-612$ & $\begin{array}{l}\text { (Schwartz and } \\
\text { Donnelly 2014) }\end{array}$ \\
\hline
\end{tabular}

Table 2: Editors-in-Chief of the International Journal of Biometeorology

\begin{tabular}{|l|l|l|}
\hline Editor-in-Chief & Years & Volumes \\
\hline Solco W Tromp, The Netherlands, Geophysics & $1957-1961$ & $1-4$ \\
\hline Wolf H Weihe, Switzerland & $1962-1981$ & $5-25$ \\
\hline R W Gloyne, Great Britain, Meteorology & $1982-1986$ & $26-30$ \\
\hline Helmut Lieth, Germany & $1987-1993$ & $31-37$ \\
\hline lan F G Hampton, United Kingdom & $1994-1995$ & $38-39$ \\
\hline Masami Iriki, Japan, Thermophysiology & $1996-2003$ & $40-48$ \\
\hline Masaaki Shibata, Japan & $2004-2007$ & $48-51$ \\
\hline Scott Sheridan, USA, Geography & 2008 -present & 52 - current \\
\hline
\end{tabular}




\section{Appendix 1}

List of the Executive Board Members of the International Society of Biometeorology and the terms they served. Disciplines are listed when known. For members who served multiple terms the discipline is listed with their first term. This excludes Editors-in-Chief who are given in Table 2.

\begin{tabular}{|c|c|c|c|c|c|}
\hline Years & $\begin{array}{l}\text { President, } \\
\text { country, } \\
\text { discipline }\end{array}$ & $\begin{array}{l}\text { Vice-presidents, } \\
\text { country, discipline }\end{array}$ & $\begin{array}{l}\text { Secretary, } \\
\text { country, } \\
\text { discipline }\end{array}$ & $\begin{array}{l}\text { Treasurer, } \\
\text { country, } \\
\text { discipline }\end{array}$ & $\begin{array}{l}\text { Advisory members", } \\
\text { Councillors* or Observers^, } \\
\text { country, discipline }\end{array}$ \\
\hline $\begin{array}{l}1956- \\
1957\end{array}$ & $\begin{array}{l}\text { Frederick } \\
\text { Sargent II, USA, } \\
\text { Physiology }\end{array}$ & $\begin{array}{l}\text { Hellmut Berg, } \\
\text { Germany } \\
\text { Hugo Boyko, Israel, } \\
\text { Botany }\end{array}$ & $\begin{array}{l}\text { Solco W } \\
\text { Tromp, The } \\
\text { Netherlands, } \\
\text { Geology }\end{array}$ & $\begin{array}{l}\text { Solco W } \\
\text { Tromp, The } \\
\text { Netherlands }\end{array}$ & A. Taylor ${ }^{\#}$, Great Britain \\
\hline $\begin{array}{l}1957- \\
1960\end{array}$ & $\begin{array}{l}\text { Frederick } \\
\text { Sargent II, USA }\end{array}$ & $\begin{array}{l}\text { P M Austin Bourke, } \\
\text { Ireland } \\
\text { Meteorology } \\
\text { Hugo Boyko, Israel, } \\
\text { M. Fontaine, } \\
\text { France, Physiology }\end{array}$ & $\begin{array}{l}\text { Solco W } \\
\text { Tromp, The } \\
\text { Netherlands }\end{array}$ & $\begin{array}{l}\text { Solco W } \\
\text { Tromp, The } \\
\text { Netherlands }\end{array}$ & $\begin{array}{l}\text { John L Cloudsley- } \\
\text { Thompson", Great Britain, } \\
\text { Entomology } \\
\text { Shinji Itoh }{ }^{\#, ~ J a p a n, ~} \\
\text { Physiology } \\
\text { William G Wellington", } \\
\text { Canada, Entomology }\end{array}$ \\
\hline $\begin{array}{l}1960- \\
1963\end{array}$ & $\begin{array}{l}\text { Frederick } \\
\text { Sargent II, USA }\end{array}$ & $\begin{array}{l}\text { P M Austin Bourke, } \\
\text { Ireland } \\
\text { Hugo Boyko, Israel } \\
\text { M. Fontaine, France }\end{array}$ & $\begin{array}{l}\text { Solco W } \\
\text { Tromp, The } \\
\text { Netherlands }\end{array}$ & $\begin{array}{l}\text { Solco W } \\
\text { Tromp, The } \\
\text { Netherlands }\end{array}$ & $\begin{array}{l}\text { John L Cloudsley- } \\
\text { Thompson", Great Britain } \\
\text { Shinji Itoh", Japan } \\
\text { William G Wellington", } \\
\text { Canada }\end{array}$ \\
\hline $\begin{array}{l}1963- \\
1966\end{array}$ & $\begin{array}{l}\text { Frederick } \\
\text { Sargent II, USA }\end{array}$ & $\begin{array}{l}\text { P M Austin Bourke, } \\
\text { Ireland } \\
\text { B.G Metz, France } \\
\text { K. Symon, then } \\
\text { Czechoslovakia, } \\
\text { Physician }\end{array}$ & $\begin{array}{l}\text { Solco W } \\
\text { Tromp, The } \\
\text { Netherlands }\end{array}$ & $\begin{array}{l}\text { Solco W } \\
\text { Tromp, The } \\
\text { Netherlands }\end{array}$ & $\begin{array}{l}\text { John L Cloudsley- } \\
\text { Thompson", Great Britain } \\
\text { Shinji Itoh", Japan } \\
\text { George W. Robertson", } \\
\text { Canada, Meteorology }\end{array}$ \\
\hline $\begin{array}{l}1966- \\
1969\end{array}$ & $\begin{array}{l}\text { Douglas H Lee, } \\
\text { USA }\end{array}$ & $\begin{array}{l}\text { George W. } \\
\text { Robertson, Canada } \\
\text { K. Symon, then } \\
\text { Czechoslovakia } \\
\text { H. Yoshimura, Japan }\end{array}$ & $\begin{array}{l}\text { Solco W } \\
\text { Tromp, The } \\
\text { Netherlands }\end{array}$ & $\begin{array}{l}\text { Solco W } \\
\text { Tromp, The } \\
\text { Netherlands }\end{array}$ & $\begin{array}{l}\text { K. Dirnagl, Germany } \\
\text { Wilbur O Haufe, Canada, } \\
\text { Entolomology } \\
\text { A. De Philippis, Italy }\end{array}$ \\
\hline $\begin{array}{l}1969- \\
1972\end{array}$ & $\begin{array}{l}\text { Douglas H Lee, } \\
\text { USA }\end{array}$ & $\begin{array}{l}\text { George W. } \\
\text { Robertson, Canada } \\
\text { K. Symon, then } \\
\text { Czechoslovakia } \\
\text { H. Yoshimura, Japan }\end{array}$ & $\begin{array}{l}\text { Solco W } \\
\text { Tromp, The } \\
\text { Netherlands }\end{array}$ & $\begin{array}{l}\text { Solco W } \\
\text { Tromp, The } \\
\text { Netherlands }\end{array}$ & $\begin{array}{l}\text { Wilbur O Haufe }{ }^{\#} \text {, Canada } \\
\text { A. De Philippis }{ }^{\#} \text {, Italy } \\
\text { P. von Deschwanden }{ }^{\#} \text { Jr, } \\
\text { Switzerland }\end{array}$ \\
\hline $\begin{array}{l}1972- \\
1975\end{array}$ & $\begin{array}{l}\text { Wilbur O } \\
\text { Haufe, Canada, } \\
\text { Entomology }\end{array}$ & $\begin{array}{l}\text { H. Hensel, } \\
\text { Germany, } \\
\text { Physiology } \\
\text { J. Jankowiak, } \\
\text { Poland, Physician } \\
\text { H. Yoshimura, } \\
\text { Japan, Physiology }\end{array}$ & $\begin{array}{l}\text { Solco W } \\
\text { Tromp, The } \\
\text { Netherlands }\end{array}$ & $\begin{array}{l}\text { Solco W } \\
\text { Tromp, The } \\
\text { Netherlands, } \\
\text { J.E } \\
\text { Greenleaf, } \\
\text { USA, }\end{array}$ & $\begin{array}{l}\text { R. Gualtierotii", Italy, } \\
\text { Physician, } \\
\text { J. A. J Stoiwijk", USA, } \\
\text { Physiology } \\
\text { P. L. von Deschwanden Jr", } \\
\text { Switzerland, Physician }\end{array}$ \\
\hline $\begin{array}{l}1976- \\
1978\end{array}$ & $\begin{array}{l}\text { Wilbur O } \\
\text { Haufe, Canada, }\end{array}$ & $\begin{array}{l}\text { H. Hensel, Germany } \\
\text { J. Jankowiak, } \\
\text { Poland } \\
\text { H. Kita, Japan }\end{array}$ & $\begin{array}{l}\text { Bernhard P } \\
\text { Primault, } \\
\text { Switzerland }\end{array}$ & $\begin{array}{l}\text { Shelley } \\
\text { Krasnow, } \\
\text { USA, } \\
\text { Biomedical } \\
\text { research }\end{array}$ & $\begin{array}{l}\text { D.F Dowling }{ }^{\#} \text {, Australia, } \\
\text { Veterinarian, } \\
\text { J. Rivolier }{ }^{\#} \text {, France } \\
\text { J. A. J Stoiwijk" , USA }\end{array}$ \\
\hline $\begin{array}{l}1980- \\
1984\end{array}$ & $\begin{array}{l}\text { Helmut Leith, } \\
\text { Germany, }\end{array}$ & $\begin{array}{l}\text { Wolfgang Bianca, } \\
\text { Switzerland, } \\
\text { Agricultural }\end{array}$ & $\begin{array}{l}\text { Bernhard P } \\
\text { Primault, } \\
\text { Switzerland }\end{array}$ & $\begin{array}{l}\text { Shelley } \\
\text { Krasnow, } \\
\text { USA }\end{array}$ & $\begin{array}{l}\text { F. Becker }{ }^{\#} \text {, Germany } \\
\text { James E Newman", USA, } \\
\text { Biometeorology, }\end{array}$ \\
\hline
\end{tabular}




\begin{tabular}{|c|c|c|c|c|c|}
\hline & & $\begin{array}{l}\text { Bioclimatology } \\
\text { P. Legris, France } \\
\text { Masakazu Kikuchi, } \\
\text { Japan }\end{array}$ & & & $\begin{array}{l}\text { Kokichi Ohara", Japan, } \\
\text { Physiology }\end{array}$ \\
\hline $\begin{array}{l}1984- \\
1988\end{array}$ & $\begin{array}{l}\text { Masakazu } \\
\text { Kikuchi, Japan, } \\
\text { Hygiene }\end{array}$ & & $\begin{array}{l}\text { Bernhard P } \\
\text { Primault, } \\
\text { Switzerland }\end{array}$ & $\begin{array}{l}\text { Shelley } \\
\text { Krasnow, } \\
\text { USA }\end{array}$ & \\
\hline $\begin{array}{l}1988- \\
1990\end{array}$ & $\begin{array}{l}\text { James E } \\
\text { Newman, USA }\end{array}$ & & $\begin{array}{l}\text { Bernhard P } \\
\text { Primault, } \\
\text { Switzerland }\end{array}$ & $\begin{array}{l}\text { Shelley } \\
\text { Krasnow, } \\
\text { USA (til Sept } \\
\text { 1989) } \\
\text { Wayne L } \\
\text { Decker, USA }\end{array}$ & \\
\hline $\begin{array}{l}1991- \\
1994\end{array}$ & $\begin{array}{l}\text { Wolf H Weihe, } \\
\text { Germany }\end{array}$ & $\begin{array}{l}\text { Masami Iriki, Japan, } \\
\text { A. Auliciems, } \\
\text { Australia }\end{array}$ & $\begin{array}{l}\text { Bernhard P } \\
\text { Primault, } \\
\text { Switzerland }\end{array}$ & $\begin{array}{l}\text { Wayne L } \\
\text { Decker, USA }\end{array}$ & $\begin{array}{l}\text { Peter R Höppe*, Germany } \\
\text { Dennis M Driscoll*, USA } \\
\text { F. Blasco*, France }\end{array}$ \\
\hline $\begin{array}{l}1994- \\
1996\end{array}$ & $\begin{array}{l}\text { Russel J Reiter, } \\
\text { USA }\end{array}$ & $\begin{array}{l}\text { Masami Iriki, Japan, } \\
\text { Peter R Höppe, } \\
\text { Germany }\end{array}$ & $\begin{array}{l}\text { Nayana N } \\
\text { Barthakur, } \\
\text { Canada, } \\
\text { Physics }\end{array}$ & $\begin{array}{l}\text { Wayne L } \\
\text { Decker, USA }\end{array}$ & $\begin{array}{l}\text { Mitsui Kosaka\#, Japan, } \\
\text { John Grace\#, United } \\
\text { Kingdom } \\
\text { LeRoy Hahn", USA, } \\
\text { Agricultural } \\
\text { Engineering/Biometeorology }\end{array}$ \\
\hline $\begin{array}{l}1997- \\
1999\end{array}$ & $\begin{array}{l}\text { Andris } \\
\text { Auliciems, } \\
\text { Australia }\end{array}$ & $\begin{array}{l}\text { Ian Burton, Canada } \\
\text { Andrej Hočevar, } \\
\text { Slovenia } \\
\text { Masami Iriki, Japan, } \\
\text { Thermophysiology }\end{array}$ & $\begin{array}{l}\text { Paul J Beggs, } \\
\text { Australia }\end{array}$ & $\begin{array}{l}\text { Wayne L } \\
\text { Decker, USA }\end{array}$ & $\begin{array}{l}\text { Jetse D Kalma*, Australia, } \\
\text { Environmental Engineering } \\
\text { Monique Leclerc*, USA } \\
\text { Ivo Martinac*, Sweden }\end{array}$ \\
\hline $\begin{array}{l}1999- \\
2002\end{array}$ & $\begin{array}{l}\text { Peter Höppe, } \\
\text { Germany }\end{array}$ & $\begin{array}{l}\text { Andrej Hočevar, } \\
\text { Slovenia } \\
\text { Monique Leclerc, } \\
\text { USA }\end{array}$ & $\begin{array}{l}\text { Paul J Beggs, } \\
\text { Australia }\end{array}$ & $\begin{array}{l}\text { LeRoy Hahn, } \\
\text { USA }\end{array}$ & $\begin{array}{l}\text { Andris Auliciems*, Australia } \\
\text { Richard de Dear*, Australia, } \\
\text { Climatology } \\
\text { Laurence S Kalkstein*, USA } \\
\text { Wopke Rietveld*, The } \\
\text { Netherlands } \\
\text { Chris de Freitas", New } \\
\text { Zealand } \\
\text { Mark Schwartz }{ }^{\#} \text {, USA } \\
\text { Masaaki Shibata", Japan } \\
\text { William Selvamurthy }{ }^{\#} \text {, India }\end{array}$ \\
\hline $\begin{array}{l}2002 \\
-2005\end{array}$ & $\begin{array}{l}\text { Ian Burton, } \\
\text { Canada }\end{array}$ & $\begin{array}{l}\text { Paul J Beggs, } \\
\text { Australia, } \\
\text { Gerd Jendritzky, } \\
\text { Germany }\end{array}$ & $\begin{array}{l}\text { Scott } \\
\text { Greene, USA }\end{array}$ & $\begin{array}{l}\text { LeRoy Hahn, } \\
\text { USA }\end{array}$ & $\begin{array}{l}\text { Andreas Matzarakis*, } \\
\text { Germany } \\
\text { Osamu Shido*, Japan } \\
\text { Karen Tomic*, USA } \\
\text { Daniel Cooper }{ }^{\#} \text {, USA } \\
\text { Kristie Ebi", USA } \\
\text { Michael Kimlin", USA } \\
\text { Wopke Rietveld", The } \\
\text { Netherlands } \\
\text { Mark Schwartz }{ }^{\#} \text {,USA } \\
\text { Kyaw Tha Pau U\#, USA }\end{array}$ \\
\hline $\begin{array}{l}2005- \\
2008\end{array}$ & $\begin{array}{l}\text { Laurence S } \\
\text { Kalkstein, USA }\end{array}$ & $\begin{array}{l}\text { Gerd Jendritzky, } \\
\text { Germany } \\
\text { Mark Schwartz, USA }\end{array}$ & $\begin{array}{l}\text { Scott } \\
\text { Greene, USA }\end{array}$ & $\begin{array}{l}\text { LeRoy Hahn, } \\
\text { USA }\end{array}$ & $\begin{array}{l}\text { Xiaoqiu Chen*, China } \\
\text { Hesham Khalifa*, Egypt } \\
\text { Glenn McGregor*, UK, } \\
\text { Geography } \\
\text { Karen Tomic*, Canada }\end{array}$ \\
\hline 2008 & Paul J Beggs, & Andreas & Mark D & John & Tanja Cegnar*, Slovenia \\
\hline
\end{tabular}




\begin{tabular}{|c|c|c|c|c|c|}
\hline 2011 & Australia & $\begin{array}{l}\text { Matzarakis, } \\
\text { Germany } \\
\text { Masaaki Shibata, } \\
\text { France }\end{array}$ & $\begin{array}{l}\text { Schwartz, } \\
\text { USA }\end{array}$ & $\begin{array}{l}\text { Gaughan, } \\
\text { Australia }\end{array}$ & $\begin{array}{l}\text { Pablo Fernandez de } \\
\text { Arroyabe Hernaez*, Spain, } \\
\text { Geography } \\
\text { Hesham Khalifa*, Egypt } \\
\text { Chris de Freitas^, New } \\
\text { Zealand } \\
\text { LeRoy Hahn^, USA, } \\
\text { Wopke Rietveld^, The } \\
\text { Netherlands }\end{array}$ \\
\hline $\begin{array}{l}2011- \\
2014\end{array}$ & $\begin{array}{l}\text { Glenn R } \\
\text { McGregor, } \\
\text { New Zealand }\end{array}$ & $\begin{array}{l}\text { Chris de Freitas, } \\
\text { New Zealand } \\
\text { Pablo Fernandez de } \\
\text { Arroyabe Hernaez, } \\
\text { Spain }\end{array}$ & $\begin{array}{l}\text { Mark D } \\
\text { Schwartz, } \\
\text { USA }\end{array}$ & $\begin{array}{l}\text { John } \\
\text { Gaughan, } \\
\text { Australia }\end{array}$ & $\begin{array}{l}\text { Lynda Chambers*, Australia, } \\
\text { Phenology and Traditional } \\
\text { Knowledge } \\
\text { Robert E Davis*, USA, } \\
\text { Climatology } \\
\text { Elena Grigorieva, Russian } \\
\text { Federation, Biometeorology } \\
\text { Tanja Cegnar^, Slovenia } \\
\text { LeRoy Hahn^, USA } \\
\text { Hesham Khalifa^, Egypt } \\
\text { Wopke Rietveld^, The } \\
\text { Netherlands } \\
\text { Shouraseni Sen Roy^, USA }\end{array}$ \\
\hline $\begin{array}{l}2014- \\
2017\end{array}$ & $\begin{array}{l}\text { Mark D } \\
\text { Schwartz, USA }\end{array}$ & $\begin{array}{l}\text { Elena Grigorieva, } \\
\text { Russian Federation } \\
\text { Marie R Keatley, } \\
\text { Australia, Plant } \\
\text { Ecology }\end{array}$ & $\begin{array}{l}\text { Jonathan M } \\
\text { Hanes, USA }\end{array}$ & $\begin{array}{l}\text { John } \\
\text { Gaughan, } \\
\text { Australia }\end{array}$ & $\begin{array}{l}\text { Hesham H. Khalifa*, Egypt } \\
\text { Junhu Dai*, China } \\
\text { Simon N. Gosling*, England } \\
\text { Luis Bartolomé Lecha } \\
\text { Estela*, Cuba, Meteorology } \\
\text { Robert E. Davis*, USA } \\
\text { Lynda Chambers*, Australia }\end{array}$ \\
\hline
\end{tabular}




\section{University Library}

\section{- M M N E R VA A gateway to Melbourne's research publications}

Minerva Access is the Institutional Repository of The University of Melbourne

Author/s:

Keatley, MR

Title:

Developments in the International Society of Biometeorology over the decade, 2007-2016

Date:

2017-09-01

Citation:

Keatley, M. R. (2017). Developments in the International Society of Biometeorology over the decade, 2007-2016. INTERNATIONAL JOURNAL OF BIOMETEOROLOGY, 61 (Suppl 1), pp.S11-S18. https://doi.org/10.1007/s00484-017-1396-z.

Persistent Link:

http://hdl.handle.net/11343/283151 